\title{
Islamic Economics as A New Current of Economic Development in Indonesia
}

\author{
Iskandar ${ }^{1}$ \\ ${ }^{1}$ Faculty of Islamic Economics and Business IAIN Salatiga, Indonesia \\ iskandarchang@iainsalatiga.ac.id ${ }^{1}$
}

Masuk: 5 September 2018, Diterima: 14 Februari 2019, Terbit: 22 Februari 2019

\begin{abstract}
This study explores to provide an alternative solution to the problems of Indonesian economy through the empowerment and embodiment of Indonesia's Islamic economy, by looking at the problems of income distribution, economic inequality and the problem of industrialization. This issue provides a new point of view that Islamic economics is not merely a banking issue. The methodology used in this study is an explanation by describing the phenomena that exist through quantitative and qualitative data. The results of this discussion are expected to provide policy direction for policy makers in solving problems related to industrialization, income distribution and inequality. The main problem of Indonesia's economic development is the lack of wisdombased development ethics. Lesson in this study is the new current of Islamic economics. Nonusury economic solutions based on wisdom in Islam. Islamic economics has experienced many developments and are increasingly embedded in the hearts of Indonesian muslims. Potency of zakat and waqf endowments, fair income distribution and the process of distribution through the mechanism of production and zakat may render solutions for income disparity and poverty alleviation.
\end{abstract}

Keywords: Islamic economics; industrialization; income distribution; inequality

\begin{abstract}
Abstrak
Studi ini mengeksplorasi untuk memberikan solusi alternatif untuk masalah ekonomi Indonesia melalui pemberdayaan dan perwujudan ekonomi Islam Indonesia, dengan melihat masalah distribusi pendapatan, ketimpangan ekonomi dan masalah industrialisasi. Masalah ini memberikan sudut pandang baru bahwa ekonomi Islam bukan hanya masalah perbankan. Metodologi yang digunakan dalam penelitian ini adalah penjelasan dengan menggambarkan fenomena yang ada melalui data kuantitatif dan kualitatif. Hasil diskusi ini diharapkan dapat memberikan arahan kebijakan bagi para pembuat kebijakan dalam menyelesaikan masalah yang terkait dengan industrialisasi, distribusi pendapatan dan ketidaksetaraan. Masalah utama pembangunan ekonomi Indonesia adalah kurangnya etika pembangunan berbasis kebijaksanaan. Pelajaran dalam penelitian ini adalah arus baru ekonomi Islam. Solusi ekonomi non-riba berdasarkan kebijaksanaan dalam Islam. Ekonomi Islam telah mengalami banyak perkembangan dan semakin tertanam dalam hati umat Islam Indonesia. Potensi zakat dan wakaf wakaf, distribusi pendapatan yang adil dan proses distribusi melalui mekanisme produksi dan zakat dapat memberikan solusi untuk disparitas pendapatan dan pengentasan kemiskinan.
\end{abstract}

Kata Kunci: ekonomi Islam; industrialisasi; distribusi pendapatan; ketidaksetaraan 


\section{INTRODUCTION}

Almost all countries including Indonesia has specialties in terms of their own economy. In the first phase of economic growth, industrialization left a distinct income disparity with low wage issues. Farm land was conversed to industrial areas. Agriculture was lessened. Local wisdom and cultural values including religious worth were reduced by lenient industrial culture and pattern.

Economic disparity emerged due to a lure to the concept of trickle down effect (Aghion \& Bolton, 1997) in which major economic elites had their privileges to manage vast economic resources with the hope to give impact on people's welfare. On the contrary, they created economic gaps between wealthy and poor groups. This was indicated by the raise in Gini coefficient. The Gini coefficient becomes an indicator which shows the overal income disparity. It ranges from 0 to 1 , with the value 0 means a perfect economic equality when everyone gains equal income (Arize, Bakarezos, Kallianiotis, Malindretos, \& Phelan, 2018).

In general, the Gini index of Indonesia is considered low. This is the case when one takes nominal Gini consumption value from the National Socio-economic data (SUSENAS) and compares them internationally. The difference between the SUSENAS data and the national account might indicate that SUSENAS was probably weak in capturing upper income i.e. SUSENAS reported that only about $10 \%$ of Indonesian people consumed more than $\$ 10$ per day in 2012 (purchasing power parity in dollar, 2011). Furthermore, Gini index in Indonesia is based on consumption disparity that adjustment of consumption to income will significantly increase disparity estimation. Adjusting disparity estimation using the highest income tax might suggest that part of the richest's income in Indonesia is generally greater than that of other countries and this challenged a perception that Indonesia was relatively equal (Yusuf \& Sumner, 2015).

Economic inequality within different terms can be seen from various viewpoints. Each of them describe different nature, causes and consequences of this economic inequality. First is called inequality of income. This inequality focuses on distribution of income amongst individuals. It describes individual income and households distributed within population. Second, inequality of wealth which focuses on distribution of wealth amongst individuals or households. It describes divergence among savings including inheritance and family heritage. The third is lifetime inequality. This inequality centers at measurement of different income gained by individuals over their life span, or in other words, it focuses on determining income inequality of individuals' life. The fourth is inequality of opportunity which focuses on the association of income disparity and social mobility, especially on intergeneration inequality.

Based on the dimension of inequality, UNDCF classified inequality into five categories namely; individual inequality, territorial inequality, gender inequality, financial inequality and digital inequality (Sastra, 2017). Individual inequality, also known as vertical inequality appears among individuals and groups of people. This inequality normally highlights the highest and the lowest income of people. Different inequality which occurs among different is called interregional or territorial inequality. This type of disparity is viewed from the gap of regional growth and development. Sometimes, this inequality come up along with ethnic and identity based inequality. Gender inequality shows that in some aspects of development, women gain less active roles than men. This 
disparity takes place due to the fact that, in general, the women posses less profitable condition and position compared to the men. Next is financial inequality. It appears in the form of disparity of individual access to financial institutions like banks and other non bank institutions. The last of these categories is digital inequality. This newly kind of inequality emerges in the recent years, along with the increasing users of cellular phones and internet.

The most strikingly known inequality is in terms of wage disparity accross regions and different tenure. Labor wage within industry did not give direct impact on production workers but more on the employer's welfare, the top management and the government by regulation they made. In Indonesia, industrialization is mostly centered in Java Island. By demography, the area of Java did not show much difference in terms of population distribution. In the case of types of industry, similarity is much found. However regarding regional wage, there has been striking disparity.

These findings showed that capitalism failed to be applied in Indonesia since there was serious problem of inequality over Indonesian economy. On the basis of above phenomenon, this paper intends to seek an alternative solution for Indonesian economic problems through empowerment and manifestation of Islamic economics, by considering problems of income distribution, economic disparity and industrialization. This matter will provide a new view that Islamic economics is not merely dealing with banking.

\section{RESEARCH METHODOLOGY}

This study employed qualitative research method. The data were collected from numerous sources such as internet, journals and relevant books related to this study. As a library research, certain method was also carried out to refer to previous studies. One source of this study included qualitative data related to Indonesian economic development, ranging from the Old Order era up to present, as comparative data. As well, we seeked sources related to the new current of Indonesian economics such as data from the Central Bank of Indonesia, Indonesian Employers Association (APINDO), Ministry of Monetary Affairs, Ministry of Commerce and others. The data were processed with the use of descriptive analysis.

\section{RESULT AND DISCUSSION}

\section{Islamic Economics in Line with Pancasila Economics}

Islamic economics in Indonesia is apparently in line with system of Pancasila economics. Principles in Pancasila have reflected the system Islamic economics, system of cooperation established by the founding fathers of this Republic, and in accordance to the mandate of 1945 Constitution. However, the lenghty practise of capitalism in Indonesia has left unjustice and profound economic problems.

Basically, the system of Pancasila economics has not been completely developed that Indonesian economy underwent serious problems, massive inequality and impacted adversely to the country. This situation was not conducive, leaving other subsequent economic problems such as exchange rate, and reliance on loan with usury. This was due to unjustice economic policies which were not proper to mandate of 1945 Constitution 
(Imama, 2008).

Wisdom based socio-economics i.e. Islamic ethics is a manifested implementation of Islamic sharia in economic field. This is because human deed should not distinct from the life ethics that they hold and believe in. Some experts e.g. Hankung perceived ethics as one aspects in establishing economic justice. This means economics cannot be separated from ethical matters (Dimyati, 2007).

Indonesia, as a country involved in the world financial constellation, had suffered crises just like other countries in the world. It began with failure of West capitalism and collapse of the world financial industry. The second world crises occured as a domino effect of the US financial crises. At present the financial menace comes again, with the exchange rate of IDR 15,000 per \$ US. This psychologic rate seems to resemble a situation prior to the fall down on New Order regime which caused Suharto's resignation (Hamid, 2009).

This phenomenon hence made Islamic economic scholars, activists and Indonesian Religious Leaders (MUI) initiate Islamic economics as a new current of the Indonesian economic system. The importance of Islamic economics thoughts which become a new current in Indonesian economics made the inclusion of Islamic economics into politics of economy is therefore considered prominent. Within this regards there are at least three kinds of typology expanded in the development pattern of Islamic economics. These three kinds of typology can be described as follows:

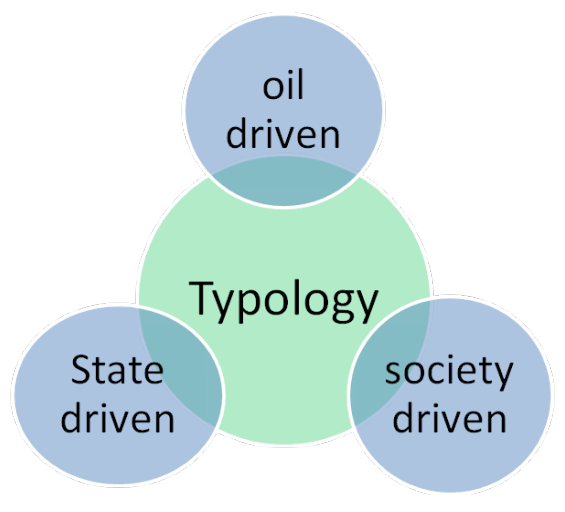

Figure 1. Typology of development of Islamic economics (Beik \& Arsyianti, 2016)

The three kinds of typology are Oil-driven Islamic (IE) system, State-driven IE system and Society-driven IE system. In the first typology, emergence of IE system was indicated by Islamic banking and financial industries stimulated by raising oil price early in 1970s. For the time being, Middle East countries earned excessive wealth. Their accumulated fund was then used to establish Islamic banking (Sharia Bank), including a multilateral institution called Islamic Development Bank (IDB) in 1974.

The second is state-driven IE system. The triggering factor of its occurence was state policies. In this case the state took an active role to develop Islamic banking and financial industry. An example of this typology is Malaysia of which government initiated Tabung Haji institution in 1969 and Bank Islam Malaysia Berhad (BIMB) as 
the first Islamic bank in 1983.

The third typology, society-driven IE system is characterized by society that initiated the Islamic banking and financial institution. MUI and ICMI set off establishment of Bank Muamalat in 1992. This is one example of Islamic economic growth initiated and supported by society (Beik \& Arsiyanti, 2016).

MUI and ICMI as well Indonesian Islamic leaders i.e. KH Mas Mansur, KH Maruf Amin, Adiwarman Karim, Muhammad Syafii Antonio, Sofyan Syafri and others have attempted to set up a new current of Indonesian economics in particular financial system. From then on there have been two financial systems in Indonesia, conventional and sharia systems. In addition, two types of financial institution are applied in Indonesia at present i.e. Bank and Non-Bank financial institutions. They have their prominent roles in achieving both sharia and national economic goals.

With regard to politics of economy, sharia economic instruments are required to be mainstream of the national economic policy. A systematic attempt is therefore needed to create an economic system with sharia policies. Three important things are included in this attempt i.e. regulation and law domain, empowerment and expansion of bank and non-bank institutions, and internalization of sharia economic values in economic life of people and the state.

In regulation domain, availability of relevant law and its derivative rules needs a critical attention. Stakeholders of sharia economics have to propose a regulation to enhance the role and growth of sharia economics. For the time being, there are only four laws issued regarding this matter i.e. Law Number 41/2004 on Waqf Endowments, Law Number 19/2008 on SBSN, Law Number 21/2008 on Sharia Banking, and Law Number 23/2011 on Zakat Management. The derivative rules are even less adequate. A continuous policy advocacy is therefore urgently needed.

Secondly, institutional expansion emphasizes efforts to expand size of sharia economic industry particularly in gaining market share for sharia banking, insurance, stock exchange, and micro financial institution (BMT) so that they can continually increase. Meanwhile, attempts are also needed to improve collection and utilization of zakat, and to develop a sharia economics teaching integrated into the national education system. The institutional expansion can certainly be enhanced with support of regulation domain, in this case the existence of supporting regulation toward development of sharia economic institutions.

Third, the internalization of sharia economic values to all nation's components is an essential effort to set a viewpoint on how to conduct economy and business in accordance to sharia guidance. These sharia economic values are expected to influence economic agents' behavior. For instance, when one understands that honesty implies worship to Allah, and that, by his deed, his zakat, infaq and alms shall or shall not be blessed by Allah, he will not corrupt or cheat (Iswanto, 2014).

Islamic economics as a new current of Indonesian economics in turns has contributed positively to the national development in Indonesia. Institutional supports of Islamic economic system as shown by the Central Bank of Indonesia, Board of Indonesian Waqf Endowments, Board of National Zakat (Baznas), and National Sharia Council have increased community's interests in Islamic economy. As a new economic power in Indonesia, Islamic economics not only gains positive supports of the community 
but also faces challenges.

Since the past decade the growth of Islamic economics has been challenged firstly, by lack of understanding on the operation of Islamic economics itself. This disparity is indicated by dominant studies of Fiqh Muamalah rather than profound, creative and prolong economic studies. Secondly, legal products in Islamic economics mostly adopt MUI fatwa, except for specific law of Islamic banking. Empirically, Islamic economics should be able to reduce inequality of income distribution as well as to enhance people's welfare. Moreover, legal corridor in Indonesia has not seemed to completely support the growth of Islamic economics.

On the other hand, it must be admitted that the growth of Islamic economics as a new current in Indonesian development cannot be separated from the historical laboratory of Indonesian economic growth. The population is mostly Muslims and this can be both strength and weakness. The on going story of Islamic economics has influenced the Muslim thoughts in Indonesia. Refusal of usury system becomes economic icon that keeps going large and wears away the conventional economics. Another force institutionaly thrusts the economic growth. The growth of Islamic economics is also driven by fundamental of Indonesian Muslims in applying Islamic teaching in terms of economy both in thought and practice levels.

On the global economic scope, since 25 September 2015 Indonesia has become one of 125 countries committed to Global Development Agenda. This commitment, as cited in UN Resolution Number 70/1, came up with UN Document to adopt transformation of development agenda post 2015: "Transforming Our World: the 2030 Agenda for Sustainable Development (Alisjahbana \& Murniningtyas, 2018) .

The agenda with the core of welfare, health, education and nutritional adequacy has become a broad economic goal including social life and environmental matters. This goal is also associated with justice and human rights. Indonesia therefore is obliged to deal actively with development for the sake of people's welfare.

Implementation of this agenda is not independent of economic politics system in Indonesia. In this case the government ought to provide opportunities, to generate social, financial and intelectual powers to comprehend economic-political equilibrium on the basis of state ideology and philosophy as cited in Preamble of 1945 Constitution (Boediono, 2016).

Islamic economics is directly related to the state politics. This means, although each of OKI member states has considered Islamic economics in formulating their economic policies, the existence of Islamic economics has not been able to match or compete the conventional economics. This implies that alignment of the authority (the government) is required to develop Islamic economics as a whole so that usury economics can be minimized (Iswanto, 2016).

Indonesia's experience of 1997-1998 crises has shown how market failure brought about adverse impact to economics. It also made the goverment overcome the crises by flowing sources to save the national economics. A large amount of fund was flowed to help economic agents (generally collapsed banks). This fund originated from people's tax and other income sources. This fact showed how market failure in capitalism which caused by speculative behavior had to be paid by people who were not beneficiary of this market economic system (Hamid, 2009). 


\section{Islamic Economics as a New Current of Economic Development in Indonesia}

In terms of Islamic economics, Indonesia recently ranked third after Malaysia in ASEAN level. This condition is supported by various sharia financial industry comprises of sharia banking and non-banking (KNKB), micro financial institution, sharia pawn and sharia stock market. The significantly contribute to the development of sharia economics in Indonesia (Antonio, Sanrego, \& Taufiq, 2012).

Islamic Financial Services Board 2013 reported that sharia banking industry in Indonesia has been more profitable than that of Malaysia. It was figured out by return on equity and return on asset values of Indonesian sharia banking that overwhelmed Malaysia's position. In terms of the market share of sharia banking, on the other hand, GIFR positioned Indonesia (5\%) as second rank after Malaysia (18\%). This attainment gives positive preference for anticipating ASEAN Economic Community in Southeast Asia. Indonesia and Malaysia have become the main actors in sharia banking sector. Since 1983 Malaysia has started their sharia financial industry with market target of $25 \%$ in 2014. Indonesia started this financial industry in 1992, with present domestic market share around 5\%. This implies that Indonesian Islamic economics actually has a remarkable potential to develop.

One aspect that can be elaborated as financial instrument of Islamic economics is huge potensial of zakat and waqf endowments due to the fact that Indonesia has the most Muslims in the world. Economic inequality with regard to income distribution, poverty and asset redistribution can be overcome with utilizing zakat and waqf endowments. Zakat, as an obligation for Muslims to share welfare with others, enables to empower poor people so that they will be better of and they can run their business, and in turns they are expected to be zakat endowers (Bahri S, 2016).

Regarding wealth distribution, Islam teaches that welfare and assets ought not to be possessed by certain community but should be shared to all people on just and proportional basis (Aprianto, 2016). This turns down success claim of market enonomics. Market economic failure to render welfare for Indonesian people has become a phenomenon needs to overcome. The government's policies and intervention are required within economic development. This is the essence of the economic development to attain better life.

Islamic economics in Indonesia has been established and run by Indonesian Muslims. The government seemed to be half hearted with its policies and financial instrument to synchronize Islamic economics. Nevertheless, at least monetary and fiscal policies of the government have involved Islamic monetary and fiscal principles. State expenditure and monetary steadiness need to be balanced by Muslims' role in the national development. A fair income distribution policy would not be present provided the government failed to act as regulator of development and welfare (Aprianto, 2016; Fadlan, 2010; Bahri S, 2016) .

One case example was aggregate expenditures whose variables were consumption, investment, government expenses and nett export. This theory was adopted by state politic system in its design of economic policy. Zakat was not regarded as a financial instrument and exempted from the aggregate expenditures. Essentially zakat should be considered an instrument in fiscal policy, not merely a principle of charity among Muslims. Zakat has a significant potential to boost economic growth and equal income 
distribution. The role of financial institution especially the Central Bank of Indonesia is deemed important to realize the policy (Iswanto, 2016).

To implement the policy, economic politics and sociology of economic politics become institution that should extend room for Islamic economics. Law and regulation, economic reinforcement, and institutionel expansion of Islamic economics need to be internalized in the context of state and society. In the law domain, regulations and their derivatives related to Islamic economics ought to be priority of economic development policy in Indonesia. Relevant stakeholders are expected to act their roles in accelerating sharia based economic development. Success in delivering four laws of sharia economics needs a follow up since sharia economics is not merely dealing with banking, waqf endowments, zakat and SBSN matters.

Another crucial matter in presenting a fair economic system on sharia basis is the role of economic and political democracy. The goverment ought to earnestly conduct economic democracy as mandated in Pancasila economic system. Should economic system not be applied thoroughly in line with political decisions, then economic democracy will only be figment. Exploitation by elites over the poor people as currently occures will not realize welfare and justice mandated by 1945 Constitution (Abbas \& Manan, 2005).

A role revealed in the study is community involvement in economic development constellation in Indonesia. Islam teaches its adherents to be productive, that they have to optimize quantity and quality of production and development. Islamic sharia also give direction that ones should utilize resources to increase productivity in the way which is sincere and blessed by Allah. Natural resources should be utilized wisely and not destructively. Two important things explained in Al Quran are discipline and deed in their positions of creating and working (Effendi, 2007). In this relevance, education and development of human resources, technological empowerment, as well as proper and virtuous utilization of nature should gain methodical attention.

\section{CONCLUSION}

Economic and political democracy practiced so far is proved to generate a deep inequality of income distribution among Indonesian people. Pancasila economic system which is essentially appropriate to Islamic principles and becomes mandate of 1945 Constitution has not been completely implemented. On the other hand, improportional capitalistic practice has led Indonesian people to a situation of economic difficulty. Nonusury economic solutions based on wisdom in Islamic sharia have experienced many developments and are increasingly embedded in the hearts of Indonesian muslims.

Islamic instruments of economic policy, funding and finance have been proven to be able to provide solutions for the worsening economic system in Indonesia. The potency of zakat and waqf endowments, a fair income distribution and equity process through production mechanism and productive zakat have been able to provide solutions for reducing inequality and poverty in Indonesia. Improvements in sharia economic management, educational development, integrating economic democracy within politics are required so as to establish political-economic regulations, based on wisdom of Islamic sharia and in accordance to mandate of 1945 Constitution. The improved system of sharia economics may bring about welfare and justice with regard to utilization of economic 
resources wisely. This will lead to common welfare and prosperity of Indonesian people.

The roles of government, community, political and economic institutions are really expected to be the main focus on developing a new current of wisdom-based economic system in Indonesia. Indonesian human resources, better off with demographic bonus, require government's attention so as to give equal part in developing sharia economics.

\section{REFERENCES}

Abbas, T., \& Manan, W. K. (2005). Keterkaitan Antara Demokrasi Politik, Demokrasi Ekonomi dan Sistem Ekonomi Kerakyatan. MIMBAR: Jurnal Sosial dan Pembangunan, 21(3), 429-439. https://doi.org/10.29313/mimbar.v21i3.186

Aghion, P., \& Bolton, P. (1997). A Theory of Trickle-Down Growth and Development. The Review of Economic Studies, 64(2), 151. https://doi.org/10.2307/2971707

Alisjahbana, A. S., \& Murniningtyas, E. (2018). Tujuan Pembangunan Berkelanjutan di Indonesia: Konsep, Target dan Strategi Implementasi (2nd ed.). Bandung: Unpad Press.

Antonio, M. S., Sanrego, Y. D., \& Taufiq, M. (2012). An Analysis of Islamic Banking Performance: Maqashid Index Implementation in Indonesia and Jordania. Journal of Islamic Finance, 1(1), 012-019.

Aprianto, N. E. K. (2016). Kebijakan Distribusi dalam Pembangunan Ekonomi Islam. Jurnal Hukum Islam, 14(2), 73-96. https://doi.org/10.28918/jhi.v0i0.693

Arize, A. C., Bakarezos, P., Kallianiotis, I. N., Malindretos, J., \& Phelan, J. (2018). The Gini Coefficient: An Application to Greece. International Journal of Economics and Finance, 10(3), 205-214, https://doi.org/10.5539/IJEF.V10N3P205.

Bahri S, A. (2016). Zakat Sebagai Instrumen Pembangunan Ekonomi Kesejahteraan Umat. $\mathrm{Li}$ Falah: Jurnal Studi Ekonomi dan Bisnis Islam, 1(2), 74-89.

Beik, I. S., \& Arsyianti, L. D. (2016). Ekonomi Pembangunan Syariah. Jakarta: Rajawali Press.

Boediono. (2016). Ekonomi Indonesia Dalam Lintasan Sejarah. Bandung: Mizan.

Dimyati, A. (2007). Ekonomi Etis: Paradigma Baru Ekonomi Islam. La_Riba: Jurnal Ekonomi Islam, 1(2), 153-168.

Effendi, M. R. (2007). Moral Islam dalam Membangkitkan Etos Ekonomi Ummat. MIMBAR: Jurnal Sosial dan Pembangunan, 23(1), 40-57. https://doi.org/10.29313/mimbar. v23i1.233

Fadlan. (2010). Konsep Pembangunan Ekonomi Berbasis Islam (Sebuah Upaya Pembangunan Ekonomi Indonesia yang Adil, Makmur, dan Sejahtera). Al Ihkam: Jurnal Hukum \& Pranata Sosial, 5(2), 257-274. http://dx.doi.org/10.19105/al-ihkam.v5i2.293

Hamid, E. S. (2009). Akar Krisis Ekonomi Global dan Dampaknya Terhadap Indonesia. La_Riba: Jurnal Ekonomi Islam, 3(1), 1-11.

Imama, L. S. (2008). Ekonomi Islam: Rasional dan Relevan. La_Riba: Jurnal Ekonomi Islam, 2(2), 309-317.

Iswanto, B. (2014). Dimensi politik hukum dalam perkembangan ekonomi Islam di Indonesia. Ijtihad : Jurnal Wacana Hukum Islam dan Kemanusiaan, 14(2), 271-284.

Iswanto, B. (2016). Peran Bank Indonesia, Dewan Syariah Nasional, Badan Wakaf Indonesia dan Baznas dalam Pengembangan Produk Hukum Ekonomi Islam di Indonesia. Iqtishadia, 9(2), 421-439. https://doi.org/10.21043/iqtishadia.v9i2

Sastra, E. (2017). Kesenjangan Ekonomi: Mewujudkan Keadilan Sosial di Indonesia. Bandung: Mizan Media Utama.

Yusuf, A. A., \& Sumner, A. (2015). Growth, Poverty, and Inequality under Jokowi. Bulletin of Indonesian Economic Studies, 51(3), 323-348. https://doi.org/10.1080/00074918.2015.1 110685 